\title{
PENERAPAN MODEL PROBLEM BASED LEARNING (PBL) DALAM PEMBELAJARAN AGAMA ISLAM UNTUK MENINGKATKAN HASIL BELAJAR SISWA KELAS XII IPS -1 SMA NEGERI 5 KOTA TERNATE TAHUN PELAJARAN 2017-2018
}

\author{
Rakib Hadi \\ Pengajar SMA Negeri 5 Ternate
}

\begin{abstract}
Abstrak
Tujuan Penelitian ini adalah untuk mendeskripsikan bagaimana penerapan model Problem Based Learning (PBL) dalam pembelajaran agama Islam untuk meningkatkan hasil belajar siswa kelas XII IPS-1 SMA N. 5 Kota Ternate. Metode yang digunakan dalam penelitian ini adalah deskriptif kualitatif, sedangkan teknik pengambilan data adalah melalui pengamatan (observasi), wawancara secara langsung maupun tidak langsung. Data dikumpulkan dengan menggunakan pedoman yakni, tes awal dan tes akhir, data dikelola secara induktif dan deduktif. Dalam penelitian ini menunjukan bahwa penerapan model problem based learning (PBL) dalam pembelajaran agama Islam untuk meningkatkan hasil belajar siswa kelas XII IPS-1 SMA N. 5 Kota Ternate dapat digunakan oleh setiap guru mata pelajaran khususnya guru agama Islam.
\end{abstract}

Kata Kunci: Problem Based Learning, Pembelajaran Agama Islam, Hasil Belajar

\section{PENDAHULUAN}

Pendidikan pada dasarnya adalah adalah usaha sadar untuk menumbuh kembangkan potensi sumber manusia peserta didik dengan cara mendorong dan memfasilitasi belajar mereka. Al Quran merupakan bukti betapa pentingnya penggunaan fungsi rana cipta dan karsa manusia dalam belajar dan merai ilmu pengetahuan. Hal ini tersirat dalam firman Allah surah az-zumar ayat 9 yang artinya:

Katakanlah: "Adakah sama orang-orang yang mengetahui dengan orangorang yang tidak mengetahui?" Sesungguhnya orang yang berakallah yang dapat menerima pelajaran.

Pendidikan terus mengalami perubahan seiring dengan perkembangan ilmu pengetahuan dan teknologi (Iptek). Pendidikan adalah upaya sadar untuk mewujudkan suasana belajar dan proses pembelajaran agar peserta didik secara aktif mengembangkan potensi dirinya untuk memiliki kekuatan spritual keagamaan, pengendalian diri, kepribadian, kecerdasan ahklak mulia, serta ketrampilan yang diperlukan dirinya dan masyarakat.

Penerapan kurikulum yang digunakan sekarang ini yaitu KTSP dan K-13, mengharuskan siswa berperan aktif dalam proses belajar mengajar. Pada kedua 
kurikulum ini guru tidak lagi mendominasi pembelajaran (teacher centered) tapi menempatkan siswa sebagai subyek didik sehingga pendekatannya berpusat pada siswa (student centered).

Mengacu pada paradigma baru guru tidak lagi merupakan pusat kegiatan belajar di kelas (teacher centered learning) tidak bisa lagi dipertahankan. Tetapi hal ini nampaknya masih banyak diterapkan diruang-ruang kelas dengan alasan pembelajaran seperti ini adalah yang paling praktis dan tidak menyita waktu. Sehingga tidak mengherankan kalau siswa cenderung jenuh, bosan dan akhirnya kurang tertarik kepada pelajaran agama. Hal ini berpengaruh terhadap hasil belajar siswa yang rendah.

Realita yang ada di sekolah-sekolah menunjukan bahwa pembelajaran agama khususnya agama Islam kurang diminati oleh peserta didik. Pelajaran agama Islam dianggap sebagai pelajaran yang membosankan hanya mendengarkan dan menghafal saja. Suatu hal yang memprihatinkan bahwa adanya anggapan dari peserta didik bahwa pelajaran agama tidak penting dan tidak memberi konstribusi bagi kehidupan kelak. Peserta didik lebih tertarik kepada ilmu eksakta yang dianggapnya memiliki konstribusi besar dalam menunjang kehidupan kelak. Sungguh ironis anggapan seperti ini, bagaimana peserta didik akan tertarik dengan pelajaran agama Islam jika mereka tidak mengetahui manfaat pelajaran agama Islam.

Proses kegiatan pembelajaran agama Islam pada umumnya juga mengalami kondisi seperti itu. Selama ini mata pelajaran agama Islam dianggap mata pelajaran yang membosankan, tidak menarik, banyak hafalan. Hal ini diperparah dengan metode konvensional yang digunakan guru agama dalam mengajar. Apabila hal ini terus dibiarkan maka siswa menjadi pasif peserta didik yang pasif tentunya susah untuk menyampaikan idea atau gagasan yang dimilikinya. Selain itu metode pembelajaran yang digunakan guru dalam mengajar kurang tepat dan kurang melibatkan partisipasi peserta didik dalam proses pembelajaran.

Berdasarkan observasi di lapangan di SMA N. 5 Kota Ternate, ternayata pembelajaran agama Islam juga mengalami hal yang sama pada umumnya yaitu guru masih menggunakan metode konvensional seperti ceramah dan masih teks book. Pada proses pembelajaran siswa terlihat pasif, berbicara dengan teman sebangkunya, dan terlihat mengantuk. Tentunya kondisi ini berdampak pada hasil belajar siswa yang rendah.

Hal tersebut merupakan kondisi serius yang perlu dan segera ditangani untuk memperbaiki kualitas pembelajaran, mengingat bahwa pelajaran agama sesungguhnya merupakan pelajaran yang penting untuk membentuk karakter bangsa. Hal ini senada dengan Djoko Suryo dalam Aman (2011: 99) bahwa pembelajaran agama harus mampu mendorong siswa berpikir kritis-analitis dalam memanfaatkan pengetahuan tentang masa lampau untuk memahami kehidupan masa kini dan yang akan datang. Mengembangkan kemampuan intektual dan ketrampilan untuk memahami proses perubahan dan keberlanjutan, dan berfungsi 
sebagai sarana untuk menanamkan kesadaran akan adanya perubahan dalam kehidupan masyarakat melalui dimensi waktu.

Dalam proses pembelajaran, pengembangan potensi peserta didik sebaiknya dilakukan secara terpadu dan menyeluruh. Seperti yang diungkapkan Aunurrahman(2009: 4) kerenanya dalam proses pembelajaran di kelas, guru tidak cukup hanya berbekal pengetahuan berkenaan dengan bidang studi yang diajarkan, akan tetapi perlu memperhatikan aspek-aspek pembelajaran secara holistik yang mendukung terwujudnya pengembangan potensi peserta didik. Guru memegang peranan strategis terutama dalam upaya membentuk watak bangsa melalui pengembangan kepribadian dan nilai-nilai yang diinginkan. Dari dimensi itu peranan guru sulit digantikan oleh yang lain Supriyadi dalam Aunurrahman (2009: 4). Proses pembelajaran sudah seharusnya meliputi proses belajar mengetahui, belajar berbuat, belajar menjadi diri sendiri dan belajar hidup bersama. Pembelajaran agama di kelas dapat mengarahkan peserta didik menjadi manusia yang mandiri dalam menyelesaikan berbagai permasalahan yang ada dikehidupan nyata. Dengan demikian pembelajaran yang ada akan bermanfaat untuk siswa dalam kehidupannya.

Model-model pembelajaran sudah banyak yang diterapkan untuk membuat pembelajaran lebih menarik bagi peserta didik. Salah satu model pembelajaran yang dapat membantu siswa dalam belajar menyelesaikan permasalahan yaitu: model pembelajaran Problem Based Learning (PBL), selanjutnya disingkat PBL. Model PBL dalam pembelajaran menempatkan siswa untuk aktif dalam pembelajaran dan guru bertindak sebagai fasilitator dimana kegiatan belajar dapat membantu mangasah kemampuan peserta didik dalam memahami konsep, menalar, memecahkan masalah dan menyampaikan idea atau gagasannya.

\section{A. Problem Based Learning (PBL)}

Menurut Howard dan Kelson dalam Taufik Amir (2010: 21) menyatakan bahwa yang dimaksud Problem Based Learning (PBL) adalah kurikulum dan proses pembelajaran, yang di dalamnya dirancang masalah-masalah yang menuntut siswa mendapatkan pengetahuan yang penting, membuat mereka mahir dalam memecahkan masalah dan memiliki strategi belajar sendiri serta memiliki kecakapan berpartisipasi dalam tim. Proses pembelajaran menggunakan pendekatan sistematik untuk memecahkan masalah atau menghadapai tantangan yang nanti diperlukan dalam karir dan kehidupan sehari-hari.

Sedangakan menurut Dutch dalam Taufik Amir (2010:21) menyatakan bahwa PBL adalah metode intruksional yang menantang siswa agar "belajar untuk belajar" bekerja sama dalam kelompok mencari solusi dalam masalah nyata. Permasalahan yang ada digunakan untuk mengkaitkan keingintahuan serta kemampuan analisis siswa dan inisiatif atas materi pelajaran. PBL mempersiapkan peserta didik untuk kritis dan analitis dan untuk mencari serta menggunakan sumber pembelajaran yang sesuai. 
Tujuan pembelajaran Problem Based Learning (PBL)adalah sebagai berikut: (1) membantu peserta didik mengembangkan ketrampilan berpikir dan ketrampilan memecahkan masalah; (2) belajar berperan sebagai orang dewasa yang autentik; dan (3) menjadikan peserta didik yang mandiri Trianto (2011: 95)

Menurut Ratumanan dalam Trianto (2011: 92), pengajaran berdasarkan masalah merupakan pendekatan yang efektif untuk pengajaran proses berpikir tingkat tinggi. Pembelajaran ini membantu siswa untuk memproses informasi yang sudah jadi dalam benaknya dan menyusun pengetahuan mereka sendiri tentang dunia sosial dan sekitarnya. Pembelajaran ini cocok untuk mengembangkan pengetahuan dasar maupun kompleks.

Selanjutnya Trianto (2010:92), menambahkan model pembelajaran berdasarkan masalah menggunakan teori kontruktivis. Model ini diawali dengan menyajikan masalah nyata yang penyelesaiannya membutuhkan kerjasama antara siswa, guru memandu siswa menguraikan rencana pemecahan masalah menjadi tahap-tahap kegiatan, guru memberi contoh mengenai penggunaan ketrampilan dan strategi dibutuhkan supaya tugas-tugas tersebut dapat diselesaikan. Guru menciptakan suasana kelas yang fleksibel dan berorientasi pada upaya penyelidikan oleh siswa.

Sementara itu seorang psikolog terkenal Gestalt dalam Margareth E. Gredler (2011:74-75) menyarankan bahwa dalam pembelajaran berbasis masalah sebaiknya: (a) pada saat membuat tugas belajar atau memberikan masalah sebaiknya dalam situasi yang konkrit aktual; (b) pendampingan selama pemecahan masalah tidak boleh berupa prosedur pengulangan atau peniruan; (c) pembelajaran tidak boleh berupa seperangkat masalah yang sudah usang yang dapat dipecahkan dengan mempelajari serangkaian langkah hafalan saja.

Penerapan model Problem Based Learning (PBL) memiliki keunggulan antara lain: (a) pemecahan masalah merupakan teknik yang cukup bagus untuk lebih memahami isi pelajaran, sehingga pembelajaran lebih bermakna; (b) pemecahan masalah dapat menantang kemampuan siswa serta memberikan kepuasan untuk menemukan pengetahuan baru bagi siswa; (c) pemecahan masalah dapat menngkatkan aktivitas pembelajaran siswa; (d) pemecahan masalah dapat membantu siswa bagaimana mentransfer pengetahuan siswa untuk memahami masalah dalam kehidupan nyata; (e) pemecahan masalah dapat membantu siswa untuk mengembangkan pengetahuan barunya dan bertanggungjawab dalam pembelajaran yang dilakukan; (f) pemecahan masalah dianggap lebih menyenangkan dan disukai siswa; dan (g) pemecahan masalah dapat mengembangkan kemampuan siswa untuk berpikir kritis dan menyesuaikan dengan pengetahuan baru. Namun terdapat kekurangan model PBL, diantaranya sebagai berikut: (a) manakala siswa tidak memiliki minat atau siswa berasumsi bahwa masalah yang dipelajari sulit dipecahkan, maka akan merasa enggan untuk mencoba; (b) keberhasilan model PBL, membutuhkan cukup waktu untuk 
persiapan; dan (c) tanpa pemahaman mengapa siswa berusaha memecahkan masalah yang dipelajari, maka siswa tidak akan belajar apa yang ingin dipelajari.

\section{B. Hasil Belajar}

Menurut Fathoni Toto (2011: 14), yang dimaksud dengan hasil belajar adalah penilaian pendidikan tentang kemampuan siswa setelah melakukan aktivitas belajar. Selanjutnya hasil belajar dapat digunakan untuk memotivasi peserta didik dan guru agar dapat melakukan perbaikan dan peningkatan kualitas pembelajaran.

Sedangkan menurut Gagne dan Brigs dalam Winkel (2004: 75), terdapat 5 katagori kapabilitas hasil belajar, yaitu: (1) kemampuan intelektual (intelectual skill); (2) strategi kognitif (cognitve strategies); (3) informasi verbal (verbal information); (4) ketrampilan motorik (motor skill); dan (5) sikap (attitudes).

Selanjutnya Winkel (2004: 75), menambahkan bahwa hasil belajar bukan hanya berupa penguasaan pengetahuan, tetapi juga kecakapan dan ketrampilan dalam melihat, menganalisis dan memecahkan masalah. Hasil belajar tampak sebagai terjadinya perubahan tingkah laku pada diri siswa yang dapat diamati dan diukur dalam bentuk perubahan pengetahuan sikap dan ketrampilan. Perubahan tersebut dapat diartikan teradinya peningkatan dan pengembangan yang lebih baik dibandingkan dengan sebelumnya.

Sementara Suprijono (2012: 5), menjelaskan belajar adalah pola-pola perbuatan, nilai-nilai, pengertian-pengertian, sikap-sikap, apresiasi dan ketrampilan-ketrampilan. Selanjutnya menunjuk pemikiran Gagne dalam Suprijono (2011:5-6), menyebutkan bahwa hasil belajar berupa: (a) informasi verbal yaitu: kapabilitas mengungkapkan pengetahuan dalam bentuk bahasa, baik lisan maupun tertulis. Kemampuan merespon secara spesifik terhadap rangsangan spesifik. Kemampuan tersebut tidak memerlukan manipulasi simbol, pemecahan masalah maupun penerapan aturan; (b) ketrampilan intelektual yaitu: kemampuan mempresentasikan konsep dan lambang. Ketrampilan intelektual terdiri dari kemampuan dari mengkategorisasi, kemampuan analitis-sintesis fakta-konsep dan mengembangkan prinsip-prinsip keilmuan. Ketrampilan intektual merupakan kemampuan melakukan aktivitas kognitif bersikap khas; (c) strategi kognitif yaitu, kecakapan menyalurkan dan mengarahkan aktivitas kognitifnya sendiri. Kemampuan ini meliputi penggunaan konsep dan kaidah dalam memcahkan masalah; d) kemampuan motorik yaitu kemampuan melakukan serangkaian gerak jasmani alam urusan dan koordinasi, sehingga terwujud otomatisme, gerak jasmani; dan e) sikap adalah kemampuan menerima atau menolak objek bedasarkan penlaian terhadap objek tersebut. Sikap berupa kemampuan menginternalisasi dan ekternalisasi nilai-nlai. Sikap merupakan kemampuan menjadikan nilai-nilai menjadi standar perilaku. 
Menurut Sardiman (2006: 49-50), menyebutkan bahwa suatu hasil belajar atau suatu hasil pengajaran itu dikatakan benar-benar baik apabila memilki ciri berikut: (1) Hasil itu tahan lama dan dapat digunakan dalam kehidupan siswa dalam berbagai situasi yang akan menghadapi ujian. Kalau hasil pengajaran itu tidak tahan lama dan lekas menghilang, berarti hasil pengajaran itu tidak efektif. Guru harus mempertimbangkan berapa banyak yang diajarkan itu akan masih diingat kelak oleh subjek belajar, setelah lewat satu minggu, satu bulan, satu tahun dan seterusnya; (2) hasil itu merupakan pengetahuan asli atau otentik. Pengetahuan hasil proses belajar mengajar itu bagi siswa seolah-olah telah merupakan bagian kepribadian bagi diri setiap siswa, sehingga akan dapat mempengaruhi pandangan dan caranya mendekati suatu permasalahan. Sebab pengetahuan itu dihayati dan penuh makna bagi dirinya.

\section{Hipotesis Tindakan}

Bertolak dari pemikiran di atas, maka hipotesis yang diajukan dalam penelitian ini adalah dengan penerapan metode Problem Based Learning (PBL) dapat meningkatkan prestasi hasil belajar siswa kelas XII IPS- 1 SMA N. 5 Kota Ternate.

\section{METODE PENELTIAN}

\section{A. Pendekatan dan Jenis Penelitian}

Menurut David Hopkins (2011:87), sesuai dengan konteks permasalahan yang dikaji maka penelitian ini merupakan penelitian tindakan kelas (PTK). Penelitian tindakan mengkombinasikan tindakan substantif dan prosedur penelitian. Penelitian ini merupakan tindakan terdisiplin yang terkontrol oleh penyelidikan, usaha seseorang untuk memahami problem tertentu seraya terlibat aktif dalam proses pengembangan dan pemberdayaan.

Menurut Carr dan Kemmis dalam Mulyasa (2002:33), mengemukakan tentang penlitian tindakan: "Action research is a from self-reflective inquiry undertaken by participants (teacher, students or principals, for example)in a social (including education) situations in order to improve the rationally and justice of (a) their own social or educational practices, (b) their understanding of these practices, and (c) the stituations (and instituations) in which these practicesare carried out".

Sementara Suharsimi Arikunto (2014: 3), menjelaskan penelitian tindakan kelas adalah suatu pencermatan terhadap kegiatan belajar berupa sebuah tindakan, yang sengaja dimunculkan dan terjadi dalam sebuah kelas secara bersama. Tindakan tersebut diberikan oleh guru atau dengan arahan dari guru yang dilakukan oleh siswa.

Berdasarkan pengertian tersebut dapat disimpulkan bahwa Penelitian Tindakan Kelas (PTK) merupakan usaha atau tindakan dalam rangka memperbaiki 
proses pembelajaran berdasarkan permasalahan yang ada untuk memperbaiki kualitas pembelajaran yang dilakukan guru kepada siswanya.

\section{Subyek Penelitian}

Teknik pengambilan sampel atau subjek penelitian dalam penelitian ini menggunakan teknik purposive sampling dan snowball sampling sehingga terdapat informan kunci dan informan pendukung.Purposive sampling adalah adalah teknik penentuan sampel dengan pertimbangan pada kemampuan sampel (informan) untuk memberikan informasi selengkap mungkin kepada penulis. Sedangkan snowball sampling adalah teknik penentuan sampel dengan mula-mula menentukan sampel dalam jumlah kecil, kemudian membesar jika sampel yang telah dipilih belum memberikan informasi atau data yang dibutuhkan oleh peneliti. Informan kunci (purposive sampling) dalam penelitian ini adalah siswa kelas XII IPS-1 sebanyak tiga puluh dua orang, sedangkan informan pendukung (snowball sampling) adalah guru. Jadi subjek penelitian ini adalah siswa dan guru yang dapat memberikan informasi yang relevan dengan tujuan penelitian.

1. Prosedur Penelitian

Prosedur penelitian tindakan kelas ini meliputi empat tahapan. Secara umum langkah-langkah operasional penelitian meliputi tahap perencanaan, pelakasanaan tindakan, pengamatan dan refleksi.

1. Siklus 1

a. Perencanaan

Pada tahap ini peneliti merancang tindakan yang akan dilakukan dalam penelitian, diantaranya:

1. Melakukan pengamatan mengenai kondisi sekolah, kondisi kelas, siswa, sarana dan prasarana yang mendukung pembelajaran dan metode yang digunakan dalam pembelajaran.

2. Membuat Rencana Pelaksanaan Pembelajaran (RPP) serta kartusoal dan jawaban.

3. Menyusun dan menyiapkan lembar obsevasi berupa lembar aktifitas siswa selama mengikuti pelajaran di kelas

4. Menyusun dan membuat angket observasi kinerja guru.

5. Merancang tes soal formatif yaitu tes yang akan diberikan pada akhir siklus 1 .

Selain itu, saat penelitian guru memberikan pengantar, pengarahan dan motivasi kepada siswa pada materi yang akan dibahas dengan menggunakan metode Problem Based Learning (PBL).

b. Pelaksanaan

1. Mengelompokkan siswa (4-5) orang

2. Guru membagikan lembar masalah kepada siswa

3. Guru melakukan orientasi terhadap masalah 
4. Membagikan LKS serta alat-alat yang diperlukan seperti karton, penggaris dan spidol.

5. Guru mengawasi dan membimbing siswa jika diminta.

6. Guru membiming siswa dalam membuat hasil karyanya.

7. Guru bersama siswa membuat kesimpulan dan rangkuman secara lisan dan siswa mencatat.

c. Pengamatan

Tahap ini dilakukan bersamaan dengan tahap pelaksanaan tindakan. Ketika pembelajaran agama melalui Problem Based Learning (PBL) dilaksanakan, guru bersama peneliti akan melakukan pengamatan, pencatatan terhadap aktivitas siswa dan semua hambatan yang terjadi di kelas dengan menggunakan lembar observasi yang telah dibuat. Setelah diadakan observasi diakhir pertemuan peneliti selain melakukan pengamatan, diakhir siklus kemudian melakukan evaluasi hasil belajar siswa berupa tes formatif dengan bentuk soal-soal obyektif dan uraian dan dikerjakan secara individu yang bertujuan untuk mengetahui pemahaman siswa terhadap materi yang telah dipelajari dan untuk mengetahui peningkatan motivasi dan hasil belajar siswa.

d. Refleksi

Refleksi dilaksanakan untuk mengevaluasi pelaksanaan tindakan. Pada tahap ini, hasil yang diperoleh pada tahap observasi dan evaluasi berupa tes formatif dikumpulkan kemudian dianalisis. Dari data tersebut akan dilihat apakah telah memenuhi target yang telah diharapkan dalam ketuntasan belajar yang telah ditetapkan atau belum. Jika pada siklus I belum memenuhi target maka akan dilanjutkan kesiklus berikutnya. Kelemahan yang terjadi pada siklus I akan diperbaiki pada siklus berikutnya.

e. Observasi

Tahapan pada siklus II mengikuti tahapan pada siklus I. Rencana tindakan siklus ke-2 ini disusun berdasarkan hasil refleksi pada siklus I yang dimaksudkan sebagai penyempurnaan atau perbaikan terhadap pelaksanaan metode Problem Based Learning (PBL).

Adanya perbaikan-perbaikan ini diharapkan pada siklus ke-2 dapat diperoleh hasil yang lebih baik dibandingkan dengan sklus ke-1. Tindakan pada siklus ke-2 dilakukan berdasarkan kekurangankekurangan pada siklus ke-1 serta diusahan cara mengatasinya.

2. Tolok Ukur Keberhasilan

Kebehasilan penelitian tindakan ini akan tercermin dengan adanya peningkatan kemampuan dalam memahami materi-materi pembelajaran setelahditerapkan metode Problem Based Learning (PBL). Adapun tolok ukur indikator keberhasilan proses pembelajaran ini dapat dilihat melalui: 
1. Penerapan metode Problem Based Learning (PBL) pada siswa kelas XII IPS-1 SMA N. 5 Kota Ternate yaitu, a) kemampuan guru dalam mempersiapkan proses pembelajaran dengan membuat Rencana Pelaksanaan Pembelajaran (RPP) yang memuat singkat metode Problem Based Learning (PBL); b) kemampuan guru melaksanakan metode Problem Based Learning (PBL), sesuai dengan RPP.

2. Penerapan metode Problem Based Learning (PBL), pada kelas XII IPS1 SMA N. 5 Kota Ternate dapat meninkatkan hasil belajar siswa, jika $75 \%$ dari jumlah siswa mencapai nilai ketuntasan minimal (KKM) 76. Apabila kelas belum mencapai ketuntasan belajar, penelitian tindakan ini dilanjutkan pada siklus berikutnya yang dilakukan berdasarkan hasil refleksi dari tindakan siklus sebelumya. Pengkurannya menggunakan rumus:

$$
x=\frac{\sum x}{\sum N}
$$

Keterangan:

$\Sigma \mathrm{X}=$ Jumlah nilai siswa

$\Sigma \mathrm{N}=$ Jumlah siswa

Untuk menghitung ketuntasan belajar ada dua, yaitu ketuntasan belajar individual dan ketuntasan belajar klasikal (daya serap). Ketuntasan belajar tercapai jika nilai siswa melebihi KKM atau $\geq 76$. Jika nilai siswa $<76$ maka siswa tersebut belum mencapai ketuntasan dan belum berhasil.

Untuk menghitung daya serap digunakan rumus:

$$
P=\frac{\text { Z sis way ang tuntas belajar } \times 100 \%}{\text { ¿'siswd }}
$$

Penelitian ini dikatakan berhasil jika $75 \%$ telah mencapai KKM minimal 75.

\section{Teknik Pengumpulan Data}

Menurut Sugiyono (2013: 137), terdapat dua hal utama yang mempengaruhi kualitas data hasil penelitian, yaitu kualitas instrumen penelitian dan kualitas pengumpulan data. Kualitas instrumen penelitian berkenaan dengan validitas dan reabilitas instrument dan kualitas pengumpulan data berkenaan dengan ketepatan cara-cara yang digunakan untuk mengumpulkan data. Ada dua teknik dalam mengumpulkan data yang dapat digunakan dalam penelitian ini, yaitu; teknik tes maupun teknik nontes. Teknik nontes dalam penelitian ini berupa, observasi, wawancara, angket dan analisis dokumen.

\section{Teknik Tes}

Menurut Saifudin Azwar (2011:37), bahwa tes prestasi belajar berupa tes yang disusun secara terencana untuk mengungkap performansi maksimal subyek dalam menguasai bahan-bahan atau materi yang telah diajarkan. Dalam kegiatan pendidikan formal di kelas, tes prestasi belajar dapat 
berbentuk ulangan harian, tes formatif, tes sumatif dan ujian masuk perguruan tinggi. Seorang pengajar harus mengetahui dasar-dasar penyusunan tes prestasi belajar yang baik agar memberikan hasil yang valid dan reliabel.

Perolehan data dilakukan penulis dengan cara membuat butir soal post tes yang akan menjadikan sebagai data untuk melihat perkembangan prestasi belajar pada setiap kali pertemuan baik dalam siklus satu dan dalam siklus refleksi dapat mengukur keseluruhan isi bahan pengajaran yang akan diukur. Oleh karena itu peneliti membuat kisi-kisi soal terlebih dahulu sehingga peneliti dapat melihat penyebaran materi yang akan diujikan pada siswa kelas XII IPS-1 SMA N. 5 Kota Ternate.

\section{Wawancara}

Pada tahap ini peneliti melakukan wawancara dengan guru, siswa dan stakeholders sekolah. Teknik ini digunakan untuk memperoleh data dari informan tentang proses pelaksanaan pembelajaran, permasalahan yang dialami guru dan siswa dalam proses pembelajaran dan faktor-faktor penyebab permasalahan yang ada. Peneliti melakukan wawancara dengan siswa untuk mengetahui minat dan kondisi pembelajaran agama Islam.

\section{Angket}

Alat non tes lainnya yang digunakan peneliti berupa angket yaitu alat yang digunakan adalah seperangkat pertanyaan atau pernyataan dalam bentuk pilihan ganda atau skala sikap untuk menggali ranah afektif tentang suatu hal. Menurut Sugiyono (2013:142), kuesioner (angket) merupakan teknik pengumpulan data yang dilakukan dengan cara memberi seperangkat pertanyaan atau pernyataan tertulis kepada responden untuk dijawabnya,sedangkan Masri Singarimbun dan Soffian Efendi (1996:76), tujuan pokok pembuatan angket adalah untuk memperoleh informasi yang relevan dengan tujuan deskriptif dan reliabilitas serta validitas setinggi mungkin. Alasan penggunaan angket adalah: 1) subyek adalah orang yang paling tahu tentang sesuatu yang ada pada dirinya; 2) apa yang dinyatakan subyek kepada peneliti adalah benar dan dapat dipercaya; 3) interpretasi subyek tentang pertanyaan yang diajukan kepadanya adalah sama dengan yang dimaksudkan oleh peneliti.

\section{E. Teknik Analisis Data}

Berdasarkan data yang telah terkumpul, dilakukan analisis terhadap data tersebut, meliputi hasil serta proses tindakan yang telah dilakukan. Proses analisis dilakukan dengan beberapa cara yaitu deskriptif kualitatis.

Data yang diperoleh dianalisis secara deskriptif dengan membandingkan nilai tes tiap siklus. Sedangkan data hasil observasi digunakan analisis deskriptif kualitatif. Refleksi dilakukan dengan teknik matching atau perbandingan hasil tindakan dengan indikator kinerja yang telah ditetapkan. Interpretasi hasil analisis 
dari semua data observasi secara cermat agar dapat mencari tindakan yang tepat guna memperbaiki pembelajarannya. Jika hasil analisis dan refleksi terhadap hasil tindakan lebih baik, penelitian dianggap berhasil. Tetapi jika sebaliknya hasilnya lebih jelek maka penelitian ini dianggap belum berhasil dan selanjutnya perlu perbaikan ulang dalam siklus kegiatan kedua dan seterusnya.

\section{HASIL PENELITIAN DAN PEMBAHASAN}

\section{A. Hasil Penelitian}

\section{Observasi Pra Siklus}

Kegiatan penelitian diawali dengan wawancara terhadap guru pengampu mata pelajaran, kemudian dilanjutkan dengan observasi untuk mengetahui kondisi awal kelas yang berkaitan dengan pembelajaran agma di kelas XII IPS-1 SMA N. 5 Kota Ternate.

Berdasarkan hasil observasi dan wawancaradengan guru mata pelajaran agama Islam kelas XII IPS-1 SMA N. 5 Kota Ternate terdapat beberapa permasalahan tentang hasil belajar. Salah satu permasalahannya yaitu banyaknya siswa yang belum mencapai kriteria standar ketuntasan minimal (KKM) yang telah ditetapkan oleh pihak sekolah, yaitu 75 untuk mata pelajaran agama Islam.

Proses pembelajaran agama Islam pada awal pelajaran masih belum optimal. Hal ini dapat terlihat dari keadaan menunjukan bahwa masih terdapat beberapa siswa berada diluar kelas, banyak siswa tidak fokus terhadap apa yang disampaikan guru, asik berbisik-bisik dengan teman sebangkunya, kurang semangat, antusias, dan mengantuk. Hal tersebut terjadi terkait dengan metode mengajar yang digunakan guru juga dirasa kurang membangkitkan motivasi siswa untuk mengikuti pelajaran agama Islam dan berpusat pada guru (teacher centered). Siswa terlihat bosan mendengarkan penjelasan guru. Pembelajaran seperti ini membuat siswa cepat merasa bosan dan akan berdampak pada hasil belajar yang rendah. Dari observasi yang dilakukan penulis diperoleh data awal sebagai berikut:

\section{a. Kondisi Nilai awal Siswa}

Kondisi nilai awal siswa diperoleh peneliti dari hasil ulangan harian. Siswa yang sudah mencapai ketuntasan dalam pembelajaran berjumlah 13 anak $(40,63 \%$ dari jumlah siswa) sedangkan yang belum tuntas adalah 19 siswa $(59,37)$ dari jumlah siswa). Rata-rata nilaiteskelas XII IPS-1 SMA N. 5 Kota Ternate adalah 61.09. Nilai tertinggi 80 dan nilai terenda 40. Kondisi tersebut dapat digambarkan pada tabel berikut ini: 
Tabel: 1. Ketuntasan nilai ulangan harian Siswa Kelas XII IPS-1 SMA N. 5 Kota Ternate sebagai data awal

\begin{tabular}{|l|c|c|}
\hline \multicolumn{1}{|c|}{ Katagori } & Frekuensi & Persentase \\
\hline Tuntas & 13 & $40,63 \%$ \\
\hline Belumtuntas & 19 & $59.37 \%$ \\
\hline Jumlah & 32 & $100 \%$ \\
\hline
\end{tabular}

Berdasarkan tabel di atas dapat digambarkan dalam diagram berikut:

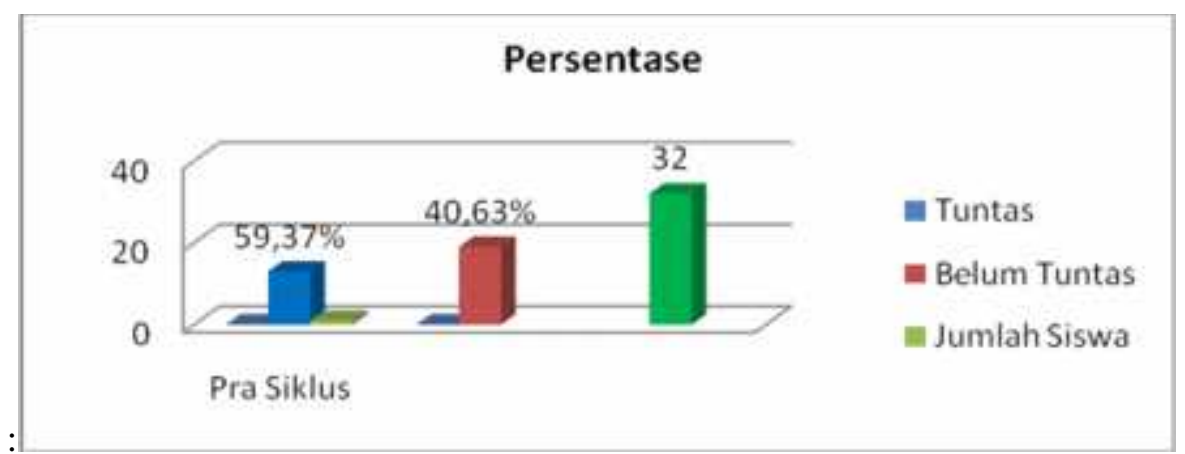

Gambar: 1. Diagram Ketuntasan Belajar Tahap Pra siklus

(Sumber: Data primer diolah, 2017)

b. Aktivitas guru dalam pembelajaran

Berdasarkan hasil observasi aktivitas guru mendapat skor 63 dengan persentase 50,4\% dengan kriteria kurang dan guru belum dapat menguasai kelas. Pada pra siklus guru belum mendorong siswa untuk aktif dalam menemukan data untuk permasalahan yang sudah diberikan. Dengan demikian aktivitas guru belum baik maka perlu dilakukan tndakan untuk memperbaiki kualitas pembelajaran dari guru.

c. Aktivitas siswa dalam pembelajaran

Berdasarkan hasil pengamaan pada pra siklus siswa belum tampak aktif mengikuti pembelajaran. Diskusi kelompok belum berjalan dengan baik. Hasil observasi tentang keaktifan siswa pra siklus ini meliputi: 1) mampu menyampaikan pertanyaan secara rasional; 2) mampu mengatasi masalah; 3) mempunyai rasa ingin tahu; 4) mampu menyampaikan ide atau pendapat; dan 5) mampu menyampaikan saran atau kritik konstruktif. 
Tabel: 2. Keaktifansiswa PraSiklus

\begin{tabular}{|l|l|c|}
\hline No & \multicolumn{1}{|c|}{ Ketuntasan } & Jumlah \\
\hline 1 & Kurang & 11 \\
\hline 2 & Cukup & 13 \\
\hline 3 & Baik & 7 \\
\hline 4 & Baik sekali & 1 \\
\hline 5 & Amat baik & 0 \\
\hline \multicolumn{2}{r|}{ Jumlah } & 32 \\
\hline
\end{tabular}

Berdasarkan data yang diperoleh dapat dilihat bahwa siswa dengan katagori kurang yaitu: 11 siswa, cukup sebanyak 13 siswa, baik berjumlah 7 siswa dan baik sekali 1, sedangkan katagori amat baik 0 .

Berdasarkan identifikasi masalah di atas penulis mencoba menerapkan sebuah metode yakni Problem Based Learning (PBL), sebagai salah satu cara untuk memecahkan permasalahan yang ada. Sebuah metode baru perlu untuk dikenalkan kepada siswa sebagai alternatif untuk memperbaiki kondisi rendahnya hasil belajar. Proses penelitian dilaksanakan dua siklus yang masing-masing siklus terdiri dari empat tahapan, yaitu: 1) perencanaan; 2) pelaksanaan tindakan; 3) observasi dan evaluasi; dan 4) analisis dan refleksi.

\section{Deskripsi Siklus I}

a. Perencanaan Tindakan Siklus I

Pada tahap perencanaan penulis mempersiapkan beberapa komponen terkait dengan materi yang disampaikan pada siklus I antara lain:

1. Membuat perencanaan pembelajaran (RPP) tentang mataeri yang akan diajarkan sesuai metode pembelajaran yang akan digunakan yaitu metode Problem Based Learning (PBL).

2. Bersama dengan guru kolaborasi, peneliti mencantumkan jadwal pelaksanaan kegiatan yaitu pada pertemuan pertama dilaksanakan pada hari rabu 17 September sedangkan pada pertemuan kedua pada hari rabu 24 September 2016 di kelas yang XII IPS-1.

3. Menyiapkan media yang akan digunakan

4. Membuat soal tes prestasi untuk mengetahui hasil belajar siswa.

b. Pelaksanaan Tindakan Siklus I

Pelaksanaan pembelajaran pada tindakan siklus I dilakukan 2 kali pertemuan di kelas XII IPS-1 dengan jumlah siswa 32. Kegiatan-kegiatan yang dilakukan pada setiap pertemuan adalah sebagai berikut: pedahuluan, kegiatan inti, dan penutup.

Pada pelaksanaan tindakan siklus I peneliti bertindak sebagai observer dan guru bertindak sebagai pengajar. Materi yang disampaikanya itu tentang iman kepada hari akhir. 


\section{Pertemuan pertama ( $3 \times 45$ menit)}

Pertemuan pertama dilaksanakan pada tanggal 17 agustus 2017. Kegiatan pertemuan pertama adalah sebagai berikut:

\section{Pendahuluan}

Pada pertemuan pertama, guru memberikan apersepsi selama 5 menit, yaitu dengan memeriksa kehadiran dan kesiapan siswa terutama tugas kelompok yang harus dipersentasikan nantinya oleh guru sesuai urutan. Setelah itu guru memberi salam dengan mengucapkan salam kemudian siswa menjawab salam dari guru.

Guru membeikan motivasi kepada siswa agar menaruh perhatian terhadap penyelesaian masalah (Fase 1). Guru kemudian mengecek kehadiaran siswa dan dilanjutkan dengan menjelaskan Kompetensi Dasar (KD) kepada siswa. Selanjutnya guru menjelaskan logistik seperti bahan-bahan dan alat yang akan diperlukan nantinya untuk menyelesaikan masalah. Dalam hal ini guru menyiapkan kertas karton, penggaris dan spidol warna. Guru meyakinkan lagi bahwa siswa sudah harus siap mengikuti pembelajaran.

\section{Kegiatan Inti}

Pada kegiatan ini guru pada awalnya menempatkan siswa sesuai dengan kelompoknya. Masing-masing kelompok diberi topik permasalahan untuk dibahas. Dalam kegiatan ini guru membantu siswa mendefinisikan dan mengorganisasikan pembelajaran yang relevan dengan penyelesaian masalah (Fase 2). Artinya bahwa guru bertindak sebagai fasilitator bagi siswa. Guru memfasilitasi terjadinya interaksi antarpeserta didik.

Guru menyemangati dan mendorong siswa untuk terus mencari informasi apa yang akan dikumpulkan, bagaimana mengolahnya, menelitinya (eksperimen) mencari penjelasan dan bagaimana menyelesaikannya (fese 3). Siswa secara kelompok mencari materi dari berbagai sumber seperti bukubuku dan internet dan kemudian mendiskusikannya untuk memecahkan rumusan masalah yang diberikan guru. Guru selalu mengingatkan kepada siswa agar tiap siswa dalam kelompok tidak boleh ada yang pasif semua harus ikut andil dalam kelompoknya.

Selanjutnya guru membantu siswa dalam mewujudkan hasil tugas mereka dalam bentuk laporan serta membantu mereka satu sama lain terkait dengan hasil karya siswanya (fase 4).

\section{Penutup}

Guru bersama siswa menyimpulkan materi yang telah dibahas Guru membantu siswa untuk merefleksi terhadap hasil penyelidikannya dan proses pembelajaran yang sudah berlangsung (fase 5). Guru memberikan pengumuman bahwa pertemuan selanjutnya akan diadakan ulangan. Guru mengakhiri pertemuan dengan mengucapkan salam. 


\section{Pertemuanm Kedua (3x45 menit)}

Pertemuan kedua dilaksanakan pada hari rabu 24 agustus 2017 sekaligus diadakan tes. Kegiatan ini adalah melaksanakan tes akhir tindakan siklus.

\section{Penadahuluan}

Guru mengawali pembelajaran dengan menyiapkan kelas terlebih dahulu dengan dipimpin salah satu siswa. Siswa menyiapkan kelasnya untuk siap mengikuti pembelajaran agama. Guru kemudian memberikan feedback bahwa kepada ketua kelas untuk melaksanakan pembelajaran dengan baik. Setelah itu guru memberi salam dan dilanjutkan dengan doa.

\section{Kegiatan Inti}

Guru kemudian mengecek kehadiran siswa dan memberikan motivasi sebelum tes dimulai. Guru langsung mendistribusikan soal pos tes kepada siswa tanpa memberi motivasi untuk percaya dengan kemampuan sendiri mungkin saja guru lupa. Pada siklus Ipada pelaksanaan tes masih tedapat beberapa siswa tengok kanan, kiri melihat hasil temanya sehingga guru perlu untuk menegur hal ini menandakan bahwa ada beberapa siswa yang belum percaya diri sehingga berusaha untuk menyontek temannya.

\section{Penutup}

Setelah semua selesai mengerjakan soal guru menutup pelajaran dengan mengucapkan salam.

\section{c. Observasi}

Pada tahap observasi dialakukan selama prose KBM berlangsung. Observasi dilakukan untuk mengetahui kondisi siswa selama proses KBM belangsung. Pada tahap ini guru menyediakan lembar observasi yang berupa kegiatan aktivitas guru dan siswa selama proses pembelajaran berlangsung.

Observasi dilakukan terhadap sikap motivasi belajar agma setelah mengikuti kegiatan pembelajaran dengan metode Preblem Based Learning (PBL). Hasil observasi pada tindakan pembelajaran siklus I dapat dipaparkan sebagai berikut:

\section{Hasil belajar siswa}

Hasil belajar siswa pada siklus I menunjukan bahwa penguasaan materi siswa mengalami peningkatan dibandingkan dengan pra siklus. Hasil tes menunjukan nilai rata-rata mengalami peningkatan dibandingkan dengan nilai pra siklus.

Tabel: 3. Tingkat ketuntasan belajar siswa siklus I

\begin{tabular}{|c|l|c|c|}
\hline No & Kriteria & Jumlah & Prosentase \\
\hline & Tuntas & 22 & $68,75 \%$ \\
\hline & Belum Tuntas & 10 & $31,25 \%$ \\
\hline
\end{tabular}

Gambar: .2. Diagram ketuntasan belajar siklus I dapat dilihat di bawah ini: 


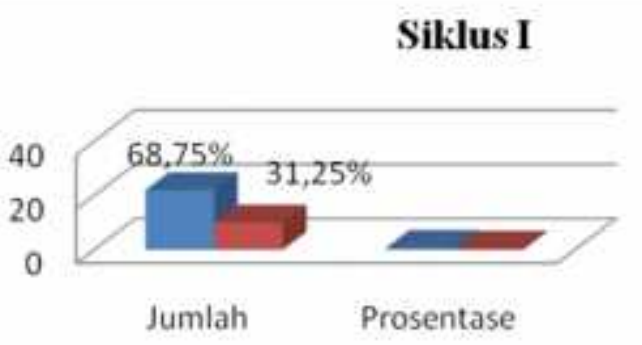

1 Tuntas

(Sumber: Data primer diolah, 2017)

\section{Aktivitas Guru dalam pembelajaran}

Berdasarkan hasil observasi terhadap aktivitas guru mendapat skor 94 dengan persentase $75,2 \%$ dengan kriteria baik sekali.Jika dibandingkan dengan kondisi pra siklus I dan guru mulai belajar menguasai kelas. Meskipun demikian prosentase penilaian guru masih belum memuaskan untuk itu perlu perbaikan pada siklus berikutnya.

\section{Aktivitas siswa dalam pembelajaran}

Berdasarkan hasil pengamatan pada siklus I siswa mulai nampak aktif mengikuti pembelajaran. Diskusi kelompok sudah berjalan baik, meskipun terdapat kelompok yang masih didominasi siswa-siswa yang pandai dan rajin.

Hasil observasi tentang keaktifan siswa siklus I meliputi: 1) mampu menyampakan pertanyaan secara rasional; 2) mampu mengatasi masalah; 3) mempunyai rasa ingin tahu; 4) mampu menyampaikan ide atau pendapat; dan 5) mampu menyampaikan saran dan kritik secara konstruktif.

Tabel 4. Keaktifan siswa siklus I

\begin{tabular}{|l|l|c|}
\hline No & Kriteria Ketuntasan & Jumlah \\
\hline 1 & Kurang & 1 \\
\hline 2 & Cukup & 8 \\
\hline 3 & Baik & 14 \\
\hline 4 & Baik sekali & 7 \\
\hline 5 & Amat baik & 2 \\
\hline \multicolumn{2}{|c|}{ Jumlah } \\
\hline
\end{tabular}

Berdasarkan data yang diperoleh dapat dilihat bahwa siswa dengan katagori kurang yaitu: 1 siswa, cukup 8 siswa, baik 14 siswa, baik sekali 7 siswa, dan amat baik berjumlah 2 siswa. 


\section{d. Refleksi Hasil Tindakan}

Berdasarkan pengamatan siklus I peneliti menemukan beberapa masalah atau kekurangan dalam pembelajaran yaitu, belumefektifnya penggunaan metode Problem Based Learning (PBL), beberapa permasalahan yang ditemukan pada sklus I menjadi acuan peneliti dan guru kembali mendiskusikan rencana perbaikan pembelajaran selanjutnya. Refleksi pada siklus I lebih baik dibandingkan dengan kondisi pra siklus, hal ini terlihat dari hasil catatan peneliti.

Pada pengamatan hasil belajar dapat dilihat dari hasil post tes yang diadakan pada pertemuan kedua. Hasil pengamatan motivasi belajar agma juga meningkat respon siswa bagus tampak senang dan antusias dalam mengikuti pelajaran. Namun demikian pada siklus I terdapat beberapa kekurangan yaitu:

1. Terdapat beberapa siswa masih merasa bingung dengan pola mengajar guru yang seolah-olah berubah. Hal ini terjadi karena guru kurang memberikan penjelasan tentang strategi pembelajaran yang akan dilaksanakan di kelas.

2. Guru lupa menyampaikan tujuan pembelajaran.

3. Laporan belum sesuai dengan harapan.

4. Ketuntasan klasikal kelas belum tercapai.

Dari beberapa kelemahan yang terdapat pada siklus I maka menjadi dasar untuk melaksanakan tindakan siklus II. Beberapa hal yang akan diperbaiki pada siklus II yaitu guru sebelumnya mensosialisasikan terlebih dahulu strategi belajar yang akan dilaksanakan di kelas agar siswa lebih paham dan guru diawal pembelajaran menyampaikan tujuan pembelajaran sebelum siswa melaksanakan kegiatan pembelajaran.

\section{Deskripsi Siklus II}

a. Perencanaan Tindakan Siklus II

Pada tahap perencanaan penulis mempersiapkan beberapa komponen terkait dengan materi yang disampaikan pada siklus II tentang Munakahat.

Hal-hal yang direncanakan pada siklus II antara lain: 1) membuat perencanaan palaksanaan pembelajaran (RPP) tentang materi yang akan diajarkan sesuai metode pembelajaran yaitu metode Problem Based Learning (PBL); 2) bersama dengan guru kolaborasi, peneliti merencanakan jadwal pelaksanaan kegiatan yaitu: pada pertemuan pertama dilaksanakan pada hari rabu 8 Oktober 2016, dan pertemuan kedua pada hari rabu tanggal 22Oktober 2016 di kelas XII IPS-1 SMA N. 5 Kota Ternate; 3) menyiapkan media yang akan digunakan; dan 4) membuat soal tes prestasi untuk mengetahui hasil belajar siswa. 
b. Pelaksanaan Tindakan Siklus II

Pelaksanaan pembelajaran pada tindakan siklus II dilakukan 2 kali pertemuan di kelas XII IPS-1 dengan jumlah siswa 32. Kegiatan-kegiatan yang dilakukan pada setiap pertemuan adalah sebagai berikut: pedahuluan, kegiatan inti, dan penutup.

Pertemuan pertama ( $3 \times 45$ menit)

Pertemuan pertama dilaksanakan pada tanggal 29 Oktober 2017. Kegiatan pertemuan pertama adalah sebagai berikut:

Pendahuluan

Pada pertemuan pertama, guru mengawali pembelajaran dengan menyiapkan kelas terlebih dahulu. Guru kemudian melakukan feed back untuk melaksanakan pembelajaran dengan baik. Setelah itu guru memberi salam kemudian siswa dijawab oleh siswa.

Guru membeikan motivasi kepada siswa agar menaruh perhatian terhadap penyelesaian masalah (Fase 1). Guru kemudian mengecek kehadiaran siswa dan dilanjutkan dengan menjelaskan Kompetensi Dasar (KD) kepada siswa. Selain itu guru menjelaskan tujuan pembelajaran yang akan dicapai nyaitu agar siswa mengetahui keimanan kepada hari akhir.Selanjutnya guru menjelaskan logistik seperti bahan-bahan dan alat yang akan diperlukan nantinya untuk menyelesaikan masalah. Dalam hal ini guru menyiapkan kertas karton, penggaris dan spidol warna. Guru meyakinkan lagi bahwa siswa sudah harus siap mengikuti pembelajaran.

Kegiatan Inti

Pada kegiatan ini guru pada awalnya menempatkan siswa sesuai dengan kelompoknya. Masing-masing kelompok diberi topik permasalahan untuk dibahas. Dalam kegiatan ini guru membantu siswa mendefinisikan dan mengorganisasikan pembelajaran yang relevan dengan penyelesaian masalah (Fase 2). Artinya bahwa guru bertindak sebagai fasilitator bagi siswa. Guru memfasilitasi terjadinya interaksi antarpeserta didik.

Guru menyemangati dan mendorong siswa untuk terus mencari informasi apa yang akan dikumpulkan, bagaimana mengolahnya, menelitinya (eksperimen) mencari penjelasan dan bagaimana menyelesaikannya (fase 3). Siswa secara kelompok mencari materi dari berbagai sumber seperti bukubuku dan internet dan kemudian mendiskusikannya untuk memecahkan rumusan masalah yang diberikan guru. Guru selalu mengingatkan kepada siswa agar tiap siswa dalam kelompok tidak boleh ada yang pasif semua harus ikut andil dalam kelompoknya.

Selanjutnya guru membantu siswa dalam mewujudkan hasil tugas mereka dalam bentuk laporan serta membantu mereka satu sama lain terkait dengan hasil karya siswanya (fase 4). Setelah semua selesai presentase bersama kelomoknya dan menunjukan hasil penyelesaian dari tiap pokok 
permasalahan yang diberikan guru pada kelompoknya dan guru bertindak sebagai fasilitator untuk mengarahkannya. Pada siklus II siswa tampak antusias dalam mengikuti pembelajaran. Hal ini terlihat jelas dengan banyaknya siswa yang berebut untuk mengajukan pertanyaan pada saat presentase. Siswa yang pandai tidak lagi mendominasi dalam presentase karena semua anggota terlibat untuk menjawab beberapa pertanyaan dari audiensi.

Penutup

Guru bersama siswa menyimpulkan materi yang telah dibahas. Guru membantu siswa untuk merefleksi terhadap hasil penyelidikannya dan proses pembelajaran yang sudah berlangsung (fase 5). Guru memberikan pengumuman bahwa pertemuan selanjutnya akan diadakan ulangan. Guru mengakhiri pertemuan dengan mengucapkan salam.

Pertemuan Kedua ( $3 \times 45$ menit)

Pertemuan kedua dilaksanakan pada hari rabu 5 Nopember 2017 sekaligus diadakan tes. Kegiatan ini adalah melaksanakan tes akhir tindakan siklus.

Penadahuluan

Guru mengawali pembelajaran dengan menyiapkan kelas terlebih dahulu dengan dipimpin salah satu siswa. Siswa menyiapkan kelasnya untuk siap mengikuti pembelajaran agma. Guru kemudian memberikan feedback bahwa kepada ketua kelas untuk melaksanakan pembelajaran dengan baik. Setelah itu guru memberi salam dan dilanjutkan dengan doa.

Kegiatan Inti

Guru kemudian mengecek kehadiran siswa dan memberikan motivasi sebelum pembelajaran dimulai agar siswa percaya dengan kemampuannya sendiri dan tidak menyontek, bertindak jujur dalam segalah hal termasuk ulangan. Guru mendistribusikan soal post tes kepada siswa dan siswa mengerjakan dengan tertib. Pada siklus II ini pada pelaksanaan tes siswa sudah tenang dan percaya diri tidak ada yang menyontek lagi.

Penutup

Setelah semua selesai mengerjakan soal guru menutup pelajaran dengan mengucapka salam.

\section{e. Observasi}

Pada tahap observasi ini dilakukan selama proses KBM dilaksanakan. Observasi dilakukan untuk mengetahui kondisi siswa selama proses KBM belangsung. Pada tahap ini guru menyediakan lembar observasi yang berupa kegiatan aktivitas guru dan siswa selama proses pembelajaran berlangsung. Observasi dilakukan terhadap sikap motivasi belajar agma setelah mengikuti kegiatan pembelajaran dengan metode Preblem Based Learning (PBL). 
Hasil observasi pada tindakan pembelajaran siklus II dapat digambarkan sebagai berikut:

\section{Hasil belajar siswa}

Hasil belajar siswa pada siklus II menunjukan bahwa penguasaan materi mengalami peningkatan dibandingkan dengan siklus I

Tabel: 5. Tingkat ketuntasan belajar siswa siklus II

\begin{tabular}{|c|l|c|c|}
\hline no & Kriteria & Jumlah & Persentase \\
\hline 1 & Tuntas & 28 & $87,5 \%$ \\
\hline 2 & Belum Tuntas & 4 & $12,5 \%$ \\
\hline \multicolumn{2}{r|}{ Jumlah } & 32 & $100 \%$ \\
\hline
\end{tabular}

(Sumber: Data primer diolah, 2016)

Gambar: 1.3. ketuntasan belajar siklus II dapat dilihat di bawah ini:

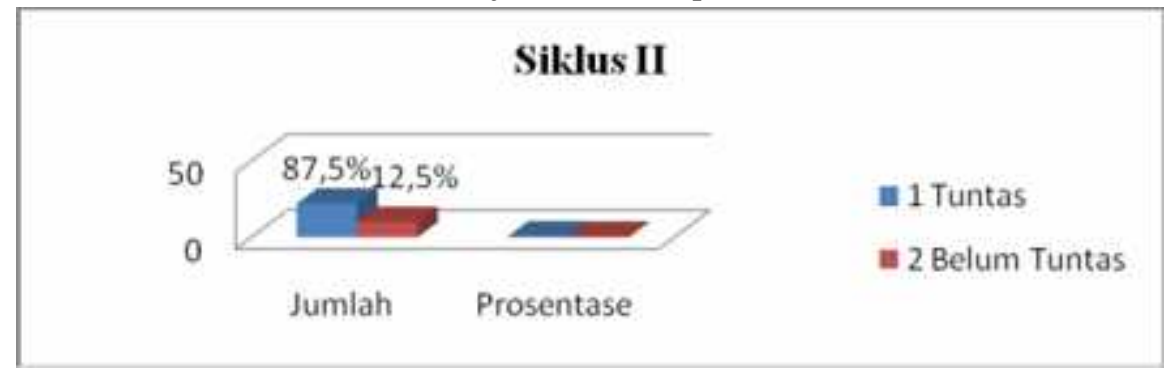

5. Aktivitas Guru dalam pembelajaran

Berdasarkan hasil observasi terhadap aktivitas guru mendapat skor 112 dengan persentase $89,6 \%$ dengan kriteria baik sekali jika dibandingkan dengan kondisi siklus I dan guru sudah dapat menguasai kelas.

Pada sisklus II guru sudah mendorong siswa untuk aktif dalam menemukan data atau informasi dari berbagai sumber untuk menyelesaikan permasalahan yang diberikan. Dengan demikian aktivitas guru sudah baik maka pembelajaran terhenti pada siklus II.

6. Aktivitas siswa dalam pembelajaran

Berdasarkan hasil pengamatan pada siklus II siswa mulai nampak aktif mengikuti pembelajaran. Diskusi kelompok sudah berjalan baik, yang pandai dan rajin tidak mendominasi lagi dalam pembelajaran hal ini terlihat semua siswa mulai aktif mengikuti pembelajaran. 
Tabel. 6. Keaktifan siswa siklus II

\begin{tabular}{|c|l|c|}
\hline No & \multicolumn{1}{|c|}{ Kriteria Ketuntasan } & Jumlah \\
\hline 1 & Kurang & 0 \\
\hline 2 & Cukup & 0 \\
\hline 3 & Baik & 6 \\
\hline 4 & Baik sekali & 15 \\
\hline 5 & Amat baik & 11 \\
\hline \multicolumn{2}{|c|}{ Jumlah } & 32 \\
\hline
\end{tabular}

Berdasarkan data yang diperoleh dapat dilihat bahwa siswa dengan katagori kurang yaitu: 0 siswa, cukup 0 siswa, baik 6 siswa, baik sekali 15 siswa, dan amat baik berjumlah 11 siswa.

\section{f. Refleksi Hasil Tindakan}

Berdasarkan pengamatan siklus II pembelajaran sudah baik dan sudah memenuhi target yang diharapkan. Pada pengamatan hasil belajar dapat dilihat dari hasil post tes yang diadakan pada siklus II sudah mencapai target. Hasil pengamatan motivasi belajar agama juga meningkat respon siswa bagus tampak senang dan antusias dalam mengkuti pelajaran.

\section{B. Pembahasan}

Penelitian ini merupakan penelitian Tindakan Kelas yang bertujuan untuk memperbaiki mutu pembelajaran agama Islam yang menyangkut hasil belajar siswa kelas XII IPS-1 SMA N 5 Kota Ternate tahun ajaran 2017/2018 dengan menggunakan metode Probelem Based Learning (PBL).

Deskripsi tersebut didasarkan pada evaluasi permasalahan yang diketahui melalui wawancara terhadap guru pengampu mata pelajaran agama Islam maupun observasi melalui proses dan hasil pembelajaran agama Islam. Berdasarkan observasi awal tersebut dapat diidentifikasi mengenai permasalahan yang terjadi yaitu hasil belajar agma kelas XII IPS-1 SMA N 5 Kota Ternate yang rendah. Metode yang dipilih untuk mengatasi masalah tersebut adalah metode Problem Based Learning (PBL).

Hasil belajar siswa pada siklus I telah mengalami peningkatan dari kondisi sebelumnya. Namun pembelajaran siklus I belum berhasil karena hasil belajar siswa belum mencapai indikator kinerja yang ditentukan yaitu $75 \%$.

Berdasarkan data hasil belajar pada kondisi awal yang diperoleh dari guru agama Islam diketahuibahwakelas XII IPS-1 memliki nilai rata-rata ulangan 61,09 dari 32 siswa hanya 13 siswa yang mencapai KKM sehingga siswa belum mencapai ketuntasan. Pada pra siklus guru masih mendomonasi pembelajaran dengan kegiatan penyampaian materi menggunakan metode ceramah sedangkan siswa pasif mendengarkan. Rutinitas tersebut menyebabkan siswa menjadi kurang 
termotivasi sehingga hasil belajar menjadi rendah. Setelah dilakukan tindakan pada siklus I dengan menerapkan metode Problem Based Learning (PBL), hasil belajar siswa meningkat ditunjukan dengan rata-rata hasil belajar menjadi 78,96 di atas rata-rata standar ketuntasan siswa adalah 76 . Untuk indikator kinerja ketuntasan sebesar $75 \%$. Siswa yang mendapat nilai lebih dari 76 adalah 22 siswa $(68,75 \%)$ sudah tuntas dan 10 siswa $(31,25 \%)$ belum tuntas dalam pembelajaran.

Dari hasil tersebut ternyata yang belum memenuhi standar ketuntasan klasikal yang sudah ditetapkan yaitu $75 \%$ sehingga penelitian dilanjutkan pada siklus II. Pada pembelajaran siklus II diperoleh data rata-rata hasil belajar siswa adalah 72,96 . Siswa yang mendapat nilai lebh dari sama dengan76 adalah 28 siswa $(87,5 \%)$ sudah tuntas dan 4 siswa $(12,5 \%)$ mendapat nilai kurang dari 76 atau belum tuntas. Sehingga dalam pembelajaran siklus II sudah berhasil karena ketuntasan klasikal kelas sudah terpenuhi yaitu lebih dari $75 \%$. Siswa telah tuntas dalam belajar yaitu, sebesar $87,5 \%$. Kondisi tersebut dapat digambarkan dalam tabel berikut:

Tabel: 7. Perbandingan Ketuntasan Hasil Belajar Siswa

\begin{tabular}{|c|c|c|c|}
\hline \multirow{2}{*}{ Kriteria } & \multicolumn{3}{|c|}{ Ketuntasan Hasil Belajar } \\
\cline { 2 - 4 } & Pra Siklus & Siklus I & Siklus II \\
\hline Tuntas & 13 & 22 & 28 \\
\hline TidakTuntas & 19 & 10 & 4 \\
\hline Jumalah & 32 & 32 & 32 \\
\hline
\end{tabular}

Berdasarkan tabel di atas dapat digambarkan dalam histogram berikut:

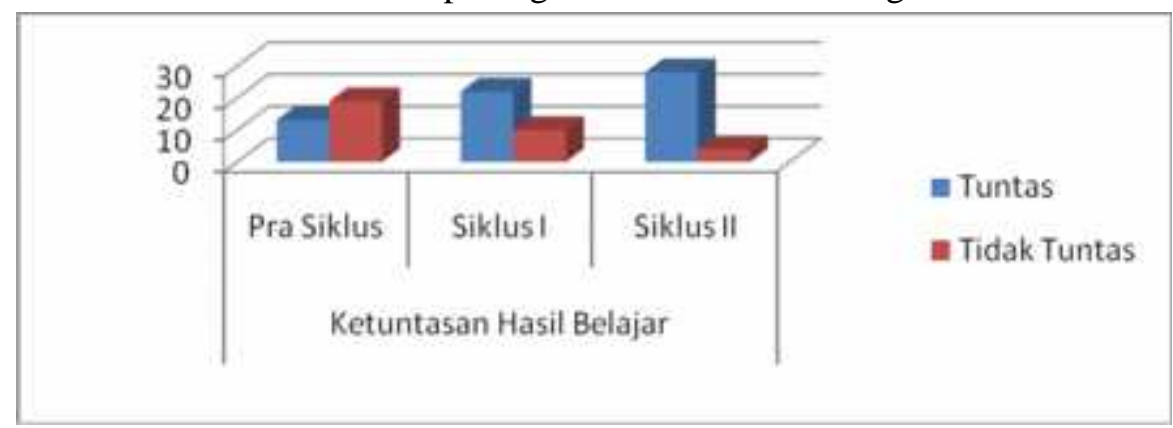

Gambar: 1.4. Diagram Ketuntasan Hasil Belajar Siswa

(Sumber: Data primer diolah, 2017)

Pada pembelajaran dengan metode Problem Based Learning (PBL), terdapat fariasi kegiatan yang melibatkan siswa secara aktif sehingga tidak membosankan. Penggunaan metode Problem Based Learning (PBL), dalam pembelajaran agama dapat meningkatkan hasil belajar siswa. Terkait hal tersebut menunjukan bahwa pembelajaran yang dilaksanakan pada siklus I belum tercapai karena masih terdapat kelemahan-kelemahan, maka penelitian tetap dilanjutkan pada siklus II 
dengan rata-rata hasil belajar 81,40 dengan ketuntasan klasikal kelas sebesar $87,5 \%$.

Dengan demikian indikator pembelajaran sudah tercapai baik, dari hasil belajar siswa. Dalam tiap siklusnya peneliti selalu melaksanakan perbaikanperbaikan demi pencapaian hasil yang maksimal dan mencapai target yang ditetapkan. Dengan demikian metode Problem Based Learning (PBL) dapat meningkatkan hasil belajar siawa mata pelajaran agama Islam kelas XII IPS-1 SMA N. 5 Kota Ternate.

Tabel 8. Rekapitulasi Hasil Belajar Pra Siklus, Siklus I dan Siklus II, dapat dilihat pada tabel beriku.

\begin{tabular}{|c|l|c|c|c|}
\hline \multirow{2}{*}{ No } & \multirow{2}{*}{ Kriteria } & \multicolumn{3}{|c|}{ Ketuntasan Hasil Belajar } \\
\cline { 3 - 5 } & & Pra Siklus & Siklus I & Siklus II \\
\hline 1 & Tuntas & 13 & 22 & 28 \\
\hline 2 & Tidak Tuntas & 19 & 10 & 4 \\
\hline 3 & Nilai rata-rata & 61,9 & 72,96 & 81,40 \\
\hline
\end{tabular}

\section{SIMPULAN}

Dari hasil pembahasan penelitian yang diuraikan sebelumnya, dapat dirumuskan beberapa kesimpulan sebagai berikut:

1. proses pelaksanaan pembelajaran dengan penerapan metode Problem Based Learning (PBL) dalam pembelajaran agama Islam pada siswa kelas XII IPS-1 dilaksanakan dalam dua siklus yang terdiri dari empat tahapan yaitu, perencanaan tindakan, pelaksanaan tindakan, observasi dan refleksi. Metode PBL dalam pembelajaran agama Islam dapat meningkatkan keefektifan belajar dan keaktifan siswa dalam proses pembelajaran.

2. penerapan metode Problem Based Learning (PBL) dalam pembelajarn agama Islam dapat meningkatkan hasil belajar siswa, hal ini dapat dilihat dari hasil belajar siswa sebagai berikut, sebelum dilaksanakan tindakan adalah sebesar 40,62\% yang tuntas, dan belum tuntas mencapai 59,37\%. Setelah dilaksanakan tindakan pada siklus I tingkat ketuntasan klasikal kelas meningakat sebesar $68,75 \%$ dan terjadi peningkatan lagi pada siklus II menjadi $87,62 \%$.

\section{DAFTAR PUSTAKA}

Amir, Taufik. 2010. Inovasi Pendidikan Melalui Problem Based Learning. Jakarta: Kencana Prenada Media Group.

Aunurrahman. 2009. Belajar dan Pembelajaran. Bandung: Alfabeta.

Dimyati \& Muldjiono. 1999. Belajar dan Pembelajaran. Jakarta: Balai Pustaka. 
Gredler, Margareth E. 2011. Learning and Instruction. Jakarta: Kencana Prenada Media Group.

La Maskone. 2011. Jurnal Pendidikan Vol. 12, Pengaruh Media Overhead Projector dan Pemberian Lembar Kerja Siswa terhadap Hasil Belajar Pendidikan Pancasila dan kewarganegaraan dan Bahasa Indonesia (Jakarta: LPPM Universitas Terbuka.

Mulyasa E. 2002. Kurikulum Berbasis Kompetensi. Bandung: Rosda Karya.

Sanjaya, Wina. 2011. Starategi Pembelajaran Berorientasi Standar Proses Pendidikan. Jakarta: Kencana Prenada Media Group.

Sardiman. 2006. Interaksi dan Motivasi Belajar. Jakarta: Raja Grafindi Persada.

Siskandar. The Strategi of Nation's Character Education. Jakarta: Journal Research and Policy, Volume 3, Number 1, 2011.

Suprijono. 2012. Cooperatif Learning Teori \& Aplikasi Paikem. Yogyakarta: Pustaka Belajar.

Toto, Fathoni. 2011. Tim Pengembang MKDP Kurikulum dan Pembelajaran. Jakarta: PT. Raja Grafindo Persada.

Trianto. 2011. Mendesain Model Pembelajaran Inovatif Progresif. Jakarta: Kencana Prenada Media Group.

Trianto. 2011. Mendesain Model Pembelajaran Inovatif Progresif. Jakarta: Kencana Prenada Media Group.

Winkel, W.S. 2004. Psikologi Pembelajaran. Yogyakarta: Media Abadi. 